\title{
A Study on the Level of $T_{3}, T_{4}$, TSH and the Association of A/G Polymorphism with CTLA-4 Gene in Graves' Hyperthyroidism among South Indian Population
}

\author{
P. Veeramuthumari • W. Isabel • K. Kannan
}

Received: 7 July 2010/Accepted: 1 December 2010/Published online: 29 December 2010

(C) Association of Clinical Biochemists of India 2010

\begin{abstract}
Graves' disease (GD) is an organ-specific heterogenous autoimmune disorder associated with T-lymphocyte abnormality affecting the thyroid, eyes and skin. GD is a multifactorial disease that develops as a result of complex interaction between genetic susceptibility genes and environmental factors. It has been suggested that the Cytotoxic T lymphocytes associated molecule-4 (CTLA-4) is a genetic susceptibility candidate for GD. The present study was focused on $\mathrm{A} / \mathrm{G}$ polymorphism at position 49 in exon- 1 of the CTLA-4 gene in 80 GD patients (GP) and 80 sex and age matched healthy individuals among South Indian (Madurai) population. Serum concentrations of thyroid hormone $\left(\mathrm{T}_{4}, \mathrm{~T}_{3}\right.$ and $\left.\mathrm{TSH}\right)$ were determined by using automated analyzer. The genomic DNA was isolated from the patient and control groups and genotyping was performed using the polymerase chain reaction followed by restriction enzyme analysis using $B b v 1$. Significant difference $(P<0.001)$ was observed in the level of $\mathrm{T}_{3}, \mathrm{~T}_{4}$ and $\mathrm{TSH}$ in GD patients and healthy individuals. The results revealed the CTLA-4 gene G/G genotype to be $32(40 \%)$ in patients and $26(32.50 \%)$ in healthy individuals, A/G genotype to be $37(46.25 \%)$ in patients and $25(31.25 \%)$ in healthy individuals and A/A genotype to be $11(13.75 \%)$ in patients and $29(36.25 \%)$ in healthy individuals. The calculated odds ratio (OR) in individuals with mutant
\end{abstract}

P. Veeramuthumari $(\bowtie) \cdot$ W. Isabel

PG and Research Department of Zoology and Biotechnology,

Lady Doak College, Madurai, Tamil Nadu 625 002, India

e-mail: muthusdream@gmail.com

K. Kannan

Madurai City Hospital and Endocrinology Clinic,

East Veli Street, Madurai, Tamil Nadu, India genotype (GG/AG) reveal 3.6 fold risk for GD (95\% confidence interval $=1.6-7.8)$. The mutant " $G$ " allele frequency was observed to be 0.63 in GD patients and 0.48 in healthy individuals. Thus the present study demonstrates an association between the CTLA-4 gene polymorphism and Graves' disease.

Keywords CTLA-4 gene - Gene polymorphism · Susceptibility · Heterogenous - Autoimmune disorder . Graves' disease

\section{Introduction}

Graves' disease (GD) is an organ specific autoimmune disorder associated with T-lymphocyte abnormality [1], in which the antibodies produced by immune system stimulates thyroid gland to produce excess of thyroxine $\left(\mathrm{T}_{4}\right)$ [2]. The normal range of $\mathrm{T}_{4}$ is suggested to be $77-155 \mathrm{nmol} / \mathrm{l}$, $\mathrm{T}_{3}$ to be $1.2-2.8 \mathrm{nmol} / \mathrm{L}$ and $\mathrm{TSH}$ to be $0.3-4 \mathrm{mU} / \mathrm{l}$ [3]. The levels of hormones above or below the normal range indicate hyperthyroidism or hypothyroidism. In Graves' hyperthyroidism, $\mathrm{T}_{3}$ and $\mathrm{T}_{4}$ levels have been reported to be increased and the TSH level to be decreased. Our finding also coincides with the above report.

The most common form of hyperthyroidism is GD. It is also a multifactorial disease that develops as the result of a complex interaction between genetic susceptibility genes and environmental factors. The susceptibility genes are human leucocyte antigen (HLA), GD-1, GD-2 and GD-3 [4] and cytotoxic T-lymphocyte associated molecule-4 (CTLA-4) [5-7]. It has been suggested that the CTLA-4 gene polymorphism plays an important role in the development of Graves' hyperthyroidism in various populations $[8,9]$. 
The CTLA-4 gene has also been implicated in several endocrine autoimmune disorders like Hoshimotos hypothyroidism [10], IDDM [5], Rheumatoid arthritis [11], Addison's disease [10] and Multiple sclerosis [12]. The CTLA-4 Ala17 is shown to be associated with IDDM and Graves' disease, whereas linkage was observed for IDDM [5].

CTLA-4 gene was discovered in a cDNA library of T-cell-specific, activation-induced genes [13]. The CTLA4 gene is reported to be located on chromosome 2 (2q33) [14]. There is increasing evidence that CTLA-4 is an extraordinarily important molecule to down regulate the $\mathrm{T}$ cell expansion and cytokine production $[15,16]$. The expression of CTLA- 4 on T cells may affect the course of an ongoing immune process $[17,18]$.

Three polymorphism sites in CTLA- 4 gene have been reported. They are (1) A/G polymorphism in exon 1, (2) $\mathrm{C} / \mathrm{T}$ polymorphism in the promoter and (3) Microsatellite repeat in the $3^{\prime}$-untranslated region of exon 4 in the CTLA4 gene. This gene has been reported to be associated with autoimmune endocrine disorders [12, 19].

A/G Single Nucleotide Polymorphism (SNP) at position 49 (exon 1, codon 17) of the CTLA4 gene leads to a Thr/ Ala substitution [20]. Studies conducted among different populations showed an association of CTLA-4 gene A/G polymorphism with Graves' disease. However, such studies are lacking among Indian population. Hence the present study associating this polymorphism (A/G polymorphism at position 49 in exon 1 of CTLA-4 gene) with Graves' disease was conducted among the population of South India (Madurai, Tamil Nadu).

\section{Materials and Methods}

In the preliminary study undertaken by us, collecting samples from an Endocrinology clinic in Madurai (TN) it was found that females are more affected (80\%) than males $(20 \%)$ and $85 \%$ of them had previous history of thyroid disease and all the patients were on antithyroid drugs. Fifty-two patients were postpartum stage. Hence female patients of age group 20-60 years were selected. The results obtained coincide with the report by Kinjo et al. [3], who studied 224 patients with GD, among whom 199 were females and only 25 were males. Their study also revealed the prevalence of GD in females than males (15-75 years old).

Eighty healthy individuals and 80 clinically proven Graves' disease patients were considered for the study. The clinical parameters used were weight, height, body mass index (BMI), TRAb level, T3, T4 and TSH levels. Fresh peripheral blood was collected in EDTA coated tubes from both healthy individuals and GD patients and stored at $-20^{\circ} \mathrm{C}$ till analysis.

The study plan was reviewed and approved by our institutional biosafety committee.

Hormone Analysis

Serum concentration of $\mathrm{T}_{4}, \mathrm{~T}_{3}$ and TSH were determined by using automated analyzer-Immunochemiluminometric analyzer (ICMA) (ADVIA Centaur). Graves' disease was confirmed when the serum $\mathrm{T}_{3}$ (normal range: 0.582-1.64 $\mathrm{ng} / \mathrm{dl}$ ), $\mathrm{T}_{4}$ (normal range: $0.39-5.60 \mathrm{ng} / \mathrm{dl}$ ) and TSH (normal range: $82-280 \mathrm{ng} / \mathrm{dl}$ ) hormone levels exceeded the normal range.

Genotyping of CTLA-4 Gene A/G Polymorphism

Genomic DNA was isolated from all the healthy individuals and GD patients from peripheral white blood cells [21]. PCR-based restriction enzyme analysis was performed in the isolated DNA. The presence of DNA was confirmed with $0.7 \%$ Agarose gel electrophoresis and the amount of DNA was quantified using UV-Spectrophotometer (Systronics).

Polymerase Chain Reaction Analysis (PCR) [3]

The DNA sequence (162 bp) of CTLA-4 gene was amplified by PCR. Genomic DNA $(0.2 \mu \mathrm{g})$ was incubated in a total reaction volume of $50 \mu \mathrm{l}$ containing $10 \mathrm{pmol}$ of both forward (5'-GCTCTACTTCCTGAAGACCT- $\left.3^{\prime}\right)$ and reverse ( $5^{\prime}$-AGTCTCACTCACCTTTGCAG- $3^{\prime}$ ) primers (Fermentas Life Sciences) for the CTLA-4 gene AlG Single Nucleotide Polymorphism (SNP) (A49G), using 2 Units of Taq DNA polymerase (Bangalore Genei, India) and dNTPs $(200 \mu \mathrm{M})$. Amplification for the CTLA-4 A49G SNP was performed with an initial denaturation of $94^{\circ} \mathrm{C}$ for $5 \mathrm{~min}$ in a thermal cycler (Eppendorf India Limited). The PCR amplification conditions were as follows: 30 cycles consisting of $30 \mathrm{~s}$ denaturation at $94^{\circ} \mathrm{C}$, $45 \mathrm{~s}$ annealing at $57^{\circ} \mathrm{C}, 30 \mathrm{~s}$ extension at $72^{\circ} \mathrm{C}$. The final cycle included a 7 min extension step at $72^{\circ} \mathrm{C}$. The PCR amplified product (162bp) was confirmed by $2 \%$ agarose gel electrophoresis under UV-transilluminator.

Restriction Enzyme Analysis [3, 9]

The CTLA-4 A49G SNP creates a Bbvl (Fermentas Life Sciences, Germany) restriction enzyme recognition sequence site. The SNP was detected by digestion of PCR amplified product $(10 \mu \mathrm{l})$ with $B b v l(0.5 \mathrm{U})$ for $3 \mathrm{~h}$ at $37^{\circ} \mathrm{C}$. Restriction fragment size analysis was performed by 
visualization of digested PCR product by $2 \%$ agarose gel electrophoresis.

\section{Statistical Analysis}

Mean and Standard deviation was calculated for hormone profile for both the healthy individuals and GD patients. Student $t$ test was performed to find out whether there was significant difference in hormone profile between the healthy individuals and GD patients. The significance level of genotype and allele frequency was tested by chi-square test $\left(\chi^{2}\right)$. Odds ratio at $95 \%$ confidence intervals were calculated.

\section{Results and Discussion}

The level of serum $\mathrm{T}_{3}$ and $\mathrm{T}_{4}$ were significantly increased $(P<0.001)$ in GD patients when compared to the healthy individuals and the level of TSH was significantly decreased in GD patients $(P<0.001)$ when compared to the healthy individuals (Table 1). Similar results were observed by several other studies [3, 20, 22].

Kinjo et al. [3] have also reported that there is increase in the level of TRA b (TSH Receptor Autoantibody) and this leads to hyperthyroidism and increased level of $\mathrm{T}_{3}$ and $\mathrm{T}_{4}$. In GD condition, binding of TRAb to the TSH receptor on the acinar cells of thyroid gland leads to continuous synthesis of thyroid hormones (T3 and T4) without involving the feedback mechanism. Thus TRAb prevents binding of TSH to its receptor [2]. Therefore, elevated $\mathrm{T}_{3}, \mathrm{~T}_{4}$ hormones suppressed the release of TSH and undetectable TSH hormone was noted in Graves' hyperthyroidism.

In the present study, the amplified PCR product (162 bp) was digested with enzyme $B b v 1$. The restriction enzyme acts on the "G" variation, but not on the "A" variation. The presence of " $G$ " allele at position 49 creates restriction sites for $B b v 1$, there by resulting in either 3 fragments (162, 88 and 74 bp-Heterozygous mutant) or 2 fragments (88 and $74 \mathrm{bp}-$ Homozygous mutant). If there is no substitution of " $G$ " allele at position then the restriction site for $B b v 1$ is abolished, as a result of which there is no cleavage of the PCR product (162 bp-Wild type-Homozygous).

Table 1 Level of serum triiodo-thyroxine $\left(\mathrm{T}_{3}\right)$, tetraiodothyroxine $\left(\mathrm{T}_{4}\right)$ and thyroid stimulating hormone (TSH) in healthy individuals and GD patients

\begin{tabular}{llll}
\hline Study subjects & $\begin{array}{l}\mathrm{T}_{3}(\mathrm{ng} / \mathrm{dl}) \\
\text { Mean } \pm \mathrm{SD}\end{array}$ & \multicolumn{1}{c}{$\begin{array}{l}\mathrm{T}_{4}(\mathrm{ng} / \mathrm{dl}) \\
\text { Mean } \pm \mathrm{SD}\end{array}$} & $\begin{array}{l}\mathrm{TSH}(\mathrm{ng} / \mathrm{dl}) \\
\text { Mean } \pm \mathrm{SD}\end{array}$ \\
\hline $\begin{array}{l}\text { GD patients }(n=80) \\
\begin{array}{l}\text { Healthy individuals } \\
(n=80)\end{array}\end{array}$ & $511.57 \pm 94.92$ & $25.95 \pm 4.48$ & $0.25 \pm 0.08$ \\
& & & \\
\hline
\end{tabular}

Table 2 Prevalence of the genotype and allele of A/G polymorphism at position 49 in exon 1 of CTLA-4 gene in GD patients and controls among South Indian population

\begin{tabular}{lll}
\hline Genotype & $\begin{array}{l}\text { GD patients } \\
(n=80)\end{array}$ & $\begin{array}{l}\text { Healthy individuals } \\
(n=80)\end{array}$ \\
\hline G/G (homozygous mutant) & $32(40 \%)$ & $26(32.50 \%)$ \\
A/G (heterozygous mutant) & $37(46.25 \%)$ & $25(31.25 \%)$ \\
A/A (homozygous normal) & $11(13.75 \%)$ & $29(36.25 \%)$ \\
Allele frequency & & \\
G (mutant) & 0.63 & 0.48 \\
A (normal) & 0.37 & 0.52 \\
\hline
\end{tabular}

There was significant difference $(P<0.05)$ between the control group and GD patients both in genotype and allelic frequency.

"G" allele frequency (0.63) was found to be significantly $(P<0.005)$ higher in GD patients than healthy individuals (0.37) (Table 2). The calculated odds ratio (OR) showed that individuals with mutant genotype (GG/AG) have 3.6 fold risk for Graves' disease (95\% confidence interval $=1.630-7.802$ ).

The distribution of genotypes ( $\mathrm{GG}, \mathrm{AG}$, and AA) for CTLA-4 gene polymorphism varies among different populations (Caucasians, Japanese, Koreans, Tunisians, Hong Kong Chinese children and Taiwanese) [6-8, 20, 23-26]. Till date, there is no study available for the prevalence of CTLA-4 gene polymorphism among GD patients in Indian population. Hence the present study associating CTLA-4 gene A49G polymorphism and Graves' hyperthyroidism was conducted among South Indian (Madurai) population.

The highest " $G$ " allele frequency $(0.76)$ was noted in Chinese GD population [20]. The lowest " $G$ " allele frequency (0.48) was noted in Caucasian GD population and among healthy individuals in Iranian (0.37) and Caucasian population $(0.38)$ [9, 12, 22]. The present study shows that the "G" allele frequency is 0.63 among South Indian population (Madurai), which is comparable to that of the Taiwanese "G" allele frequency (0.67) [23].

Susceptibility to GD has significant genetic components. CTLA-4 gene polymorphism has been reported to be associated with GD. CTLA-4 molecule is a member of the family of cell surface molecule as CD28, which binds to B7. The CTLA-4/B7 complex competes with the CD28/B7 complex and delivers negative signals to the T-cells, which affects T-cell expansion, cytokine production, and immune responses as evidenced in different populations [6-8, 23]. To conclude (i) The TSH was found to be decreased among GD patients whereas $T_{3}$ and $T_{4}$ were found to be increased. (ii) Prevalence of mutant genotype (GG) for CTLA-4 gene was found to be higher in GD patients than in healthy individuals and (iii) there is association between mutant 
genotype and GD among South Indian (Madurai) population.

\section{References}

1. Weetman AP, McGregor AM. Autoimmune thyroid disease: further development in our understanding. Endocr Rev. 1994; 15:788-830.

2. Chistiakov DA. Thyroid-stimulating hormone receptor and its role in Graves' disease. Mol Genet Metab. 2003;80(4):377-88.

3. Kinjo Y, Takasu N, Komiya I, Tomoyose T, Takara M, Kouki T, Shimajiri Y, Yabiku K, Yoshimura H. Remission of Graves' hyperthyroidism and $\mathrm{A} / \mathrm{G}$ polymorphism at position 49 in exon 1 of cytotoxic T-lymphocyte-associated molecule-4 gene. J Clin Endocrinol Metab. 2002;87(6):2593-6.

4. Tomer Y, Barbesino G, Greenberg DA, Concepcion E, Davies TF. Mapping the major susceptibility loci for familial Graves' and Hashimoto's disease evidence for genetic heterogeneity and gene interactions. J Clin Endocrinol Metab. 1999;84:4656-64.

5. Donner H, Rau H, Walfish PG, Braun J, Siegmund T, Finke R, Herwig J, Usadel KH, Badenhoop K. CTLA-4 alanine-17 confers genetic susceptibility to Graves' disease and to type 1 diabetes mellitus. J Clin Endocrinol Metab. 1997;82(1):143-6.

6. Yanagawa T, Taniyama M, Enomoto S, Gomi K, Maruyama H, Ban Y, Saruta T. CTLA-4 gene polymorphism confers susceptibility to Graves' disease in Japanese. Thyroid. 1997;7(6):843-6.

7. Park YJ, Chung HK, Park DJ, Kim WB, Kim SW, Koh JJ, Cho BY. Polymorphism in the promotor and exon 1 of the cytotoxic T lymphocyte antigen-4 gene associated with autoimmune thyroid disease in Koreans. Thyroid. 2000;10:453-9.

8. Yanagawa T, Hidaka Y, Guimaraes V, Soliman M, DeGroot LJ. CTLA-4 gene polymorphism associated with Graves' disease in a Caucasian population. J Clin Endocrinol Metab. 1995;80:41-5.

9. Bednarczuk T, Hiromatsu Y, Fukutani T, Jazdzewski K, Miskiewicz P, Osikowska M, Nauman J. Association of cytotoxic T-lymphocyte-associated antigen-4 (CTLA-4) gene polymorphism and non-genetic factors with Graves' ophthalmopathy in European and Japanese populations. Eur J Endocrinol. 2003; 148:13-8.

10. Kotsa K, Watson P, Weetman AP. A CTLA-4 gene polymorphism associated with both Graves' disease and Hoshimoto's thyroiditis. Clin Endocrinol (Oxf). 1997;46:551-4.

11. Vaidya B, Pearce SHS, Charlton S, Marshall N, Rowan AD, Griffiths ID, Kendall-Taylor P, Cawston TE, Young-Min S. An association between the CTLA- 4 exon 1 polymorphism and early rheumatoid arthritis with autoimmune endocrinopathies. Rheumatology. 2002;41:180-3.

12. Kouki T, Sawai Y, Gardine CA, Fisfalen M-E, Alegre M-L, Degroot LJ. CTLA-4 gene polymorphism at position 49 in exon 1 reduces the inhibitory function of CTLA- 4 and contributes to the pathogens of Graves, disease. J Immunol. 2000;165:6606-11.
13. Brunet JF, Denizot F, Luciani MF, Roux-Dosseto M, Suzan M, Mattei MG, Golstein P. A new member of the immunoglobulin superfamily-CTLA-4. Nature. 1987;328:267-70.

14. Heward JM, Allahabadia A, Armitage M, Hattersley A, Dodson PM, Macleod K, Carr-Smith J, Daykin J, Dally A, Sheppard MC, Holder RL, Barnett AH, Franklyn JA, Gough SC. The development of Graves' disease and the CTLA-4 gene on chromosome 2q33. J Clin Endocrinol Metab. 1999;84:2398-401.

15. Walunas TL, Lenschow DJ, Bakker CY, Linsley PS, Freeman GJ, Greene JM, Thompson CB, Bluestone JA. CTLA-4 can function as a negative regulator of T-cell activation. Immunity. 1994; $1: 405-13$

16. Chambers CA, Krummel MF, Boitel B, Hurwitz A, Sullivan TJ, Fournier S, Cassell D, Brunner M, Allison JP. The role of CTLA4 in the regulation of T-cell responses. Immunol Rev. 1996; 153:27-46.

17. Tivol EA, Borriello F, Schweitzer AN, Lynch WP, Bluestone JA, Sharpe AH. Loss of CTLA-4 leads to massive lymphoproliferation and fatal multiorgan tissue destruction: revealing a critical negative regulatory role of CTLA-4. Immunity. 1995;3:541-7.

18. Vaidya B, Imrie H, Perros P. The cytotoxic T-lymphocyte antigen-4 is a major Graves disease locus. Hum Mol Genet. 1999; 8:1195-9.

19. Kacem HH, Bellassoued M, Bougacha-Elleuch N, Mohamed A. CTLA-4 gene polymorphisms in Tunisian patients with Graves' disease. Clin Immunol. 2001;101(3):351-5.

20. Wang P-W, Liu R-T, Jou S-HH, Wang S-T, Hu Y-H, Hsieh C-J, Chen M-C, Chen I-Y, Wu C-L. Cytotoxic T lymphocyte associated molecule-4 polymorphism and relapse of Graves' hyperthyroidism after antithyroid withdrawal. J Clin Endocrinol Metab. 2004;89(1):169-73.

21. Sambrook J, Russel DW. Molecular cloning, a laboratory manual. 3rd ed. New York: Cold Springer Harbour Laboratory Press; 2001.

22. Kalantari T, Mostafavi H, Pezeshki AM, Farjadian S, Doroudchi M, Yeganeh F, Ghaderi A. Exon-1 polymorphism of ctla-4 gene in Iranian patients with Graves' disease. Autoimmunity. 2003; 36(5):313-6.

23. Weng Y-C, Wu M-J, Lin W-S. CT60 single nucleotide polymorphism of the CTLA-4 gene is associated with susceptibility to Graves' disease in the Taiwanese population. Ann Clin Lab Sci. 2005;35:259-64.

24. Chong KKL, Chiang SWY, Wong GWK, Tam POS, Ng T-K, Hu Y-J, Yam GHF, Lam DSC, Pang C-P. Association of CTLA-4 and IL-3 gene polymorphisms with Graves' disease and opthalmopathy in Chinese children. Investig Opthalmol Vis Sci. 2008;49:2409-15.

25. Yung E, Cheng PS, Fok TF, Wong GW. CTLA-4 gene A-G polymorphism and childhood Graves' disease. Clin Endocrinol. 2002;56:649-53.

26. Tomer Y, Barbesino G, Greenberg DA, Concepcion E, Davies TF. CTLA-4 and not CD28 is a susceptibility gene for thyroid autoantibody production. J Clin Endocrin Metab. 2001; 86(4):1687-93. 